\title{
Perubahan Nilai Dan Makna Baluntang Dampaknya Terhadap Pemeliharaan Dan Pelestarian BCB (Kasus di Wilayah Kabupaten Tabalong Kalimantan Selatan)
}

\section{Bambang Sugiyanto}

Keywords: cultural resource management, meaning, tradition, conservation, utilization, community

\section{How to Cite:}

Sugiyanto, B. (2005). Perubahan Nilai Dan Makna Baluntang Dampaknya Terhadap Pemeliharaan Dan Pelestarian BCB (Kasus di Wilayah Kabupaten Tabalong Kalimantan Selatan). Berkala Arkeologi, 25(1), 8-16. https://doi.org/10.30883/jba.v25i1.905

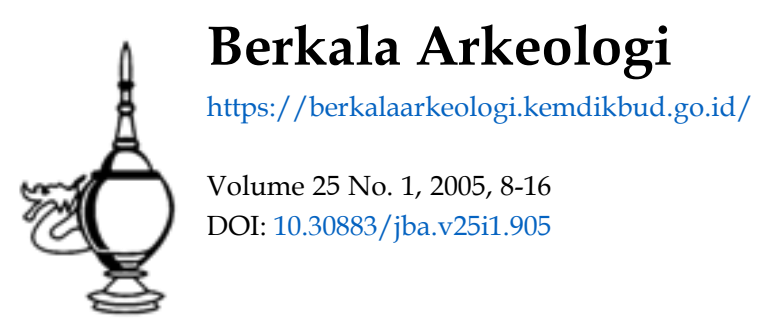

\section{c)}

This work is licensed under a Creative Commons Attribution-NonCommercial-ShareAlike 4.0 International License. 


\section{PERUBAHAN NILAI DAN MAKNA BALUNTANG \\ DAMPAKNYA TERHADAP PEMELIHARAAN DAN PELESTARIAN BCB \\ Kasus di Wilayah Kabupaten Tabalong Kalimantan Selatan}

Oleh : Bambang Sugiyanto

\section{Pendahuluan dan Batasan Pengertian}

Kabupaten Tabalong merupakan salah satu Daerah Tingkat II dalam wilayah administratif Propinsi Kalimantan Selatan yang terletak di ujung utara berbatasan dengan Kabupaten Pasir Selatan, Propinsi Kalimantan Timur. Di sebelah barat, Kabupaten Tabalong berbatasan dengan Kabupaten Barito Selatan, Propinsi Kalimantan Tengah. Sementara di sebelah selatan berbatasan dengan Kabupaten Hulu Sungai Tengah dan di sebelah Timur berbatasan dengan Kabupaten Hulu Sungai Utara.

Wilayah Kabupaten Tabalong diketahui mempunyai potensi sumberdaya budaya yang cukup baik. Sumberdaya itu antara lain berupa sumberdaya gua-gua prasejarah yang terdapat di lereng perbukitan kapur Bukit Batu Buli, di sekitar Desa Randu, Kecamatan Muara Uya, sumberdaya gua-gua penguburan tradisional yang terdapat di perbukitan kapur di sekitar Desa Dambung Raya, Kecamatan Haruai dan juga di sekitar Desa Binjai, Kecamatan Muara Uya (Kosasih dkk 1995/1996; Sulistyanto 2001), dan juga sumberdaya tentang upacara adat tradisional yang berhubungan dengan kematian atau kegiatan kehidupan lainnya.

Upacara tradisional yang diselenggarakan oleh penduduk atau masyarakat Tabalong adalah upacara Mambatur dan upacara Mambuntang. Bukti-bukti penyelenggaraan upacara tradisional itu masih dapat kita lihat pada berdirinya patung-patung kayu yang biasa disebut dengan Baluntang, yang pada umumnya terdapat di halaman depan rumah atau di halaman samping sebuah rumah penduduk. Secara umum bentuk Baluntang adalah sebuah tiang kayu ulin yang berukuran cukup besar dan panjang, di bagian atasnya dipahatkan hiasan bentuk tajau dan sebuah patung seorang tokoh yang diupacari. Pada dasarnya, Baluntang ini berfungsi sebagai tiang untuk mengikat hewan kurban pada saat upacara berlangsung. Oleh karena itu bahannya harus yang kuat dan kokoh agar dapat menahan gerakan dan tenaga kerbau yang diikat pada tiang tersebut.

Selain fungsi praktis sebagai tiang pengikat hewan kurban (kerbau), Baluntang juga mempunyai fungsi lain. Dalam kehidupan masyarakat Tabalong, Baluntang mempunyai nilai, fungsi dan arti sangat spesifik yang sarat akan nuansa religi. Oleh karena itu, Baluntang tidak dapat dibuat dan didirikan secara sembarangan oleh semua orang, karena Baluntang bukan sekedar sebuah patung kayu biasa yang dihasilkan oleh kreasi seni memahat kayu, tetapi Baluntang diyakini 
mempunyai pesan mistik-magis yang sangat dalam artinya. Menurut M.P. Lambut, pada umumnya para pemahat suku Dayak tidak hanya mengandalkan pada imajinasi dalam menghasilkan karya seni. Mereka juga menonjolkan ketajaman intuisinya untuk menangkap pesan-pesan mistik-magis dalam menghasilkan karyanya. Penangkapan pesan-pesan itu tidak boleh salah sedikit pun, karena kesalahan akan dapat mendatangkan bencana bagi si pemahat dan juga masyarakat pada umumnya. Oleh karena itu seorang seniman pembuat patung Suku Dayak harus mempunyai naluri yang tajam untuk agar dapat menangkap pesan mistikmagis dengan baik dan benar.

Demikian juga dengan Baluntang, yang secara umum mempunyai fungsi praktis sebagai tiang pengikat kerbau pada pelaksanaan upacara Mambatur atau Mambuntang. Pembuatan dan pendirian sebuah Baluntang juga mempunyai persyaratan tertentu, mulai dari pencarian bahan sampai pada proses pemahatannya. Semua kegiatan itu harus dilakukan sesuai dengan aturan adat istiadat yang berlaku. Bahkan pada saat pendiriannya pun diatur dengan adat dan tidak dapat sembarangan saja. Pada pelaksanaan upacara Mambatur yang sama dapat menggunakan Baluntang yang telah ada, sehingga tidak perlu membuat dan mendirikan yang baru. Begitu juga dengan upacara Mambuntang, dapat menggunakan Baluntang yang lama dengan syarat utama kondisi Baluntangnya masih kokoh dan kuat untuk mengikat kerbau.

Selain fungsi praktis di atas, Baluntang, juga mempunyai fungsi ideologis, yaitu sebagai penjaga keselamatan, penolak bala, dan pemberi rejeki. Sehubungan dengan fungsi ideologis tersebut, pada umumnya pendirian Baluntang kemudian diberi nama atau gelar sesuai dengan nama dewa penolong yang diharapkan oleh keluarga yang masih hidup, yang biasa disebut dengan Pangantu Pangintuhu (Hartatik 2001).

\section{Permasalahan}

Keterangan di atas menjelaskan bahwa patung Baluntang yang cukup banyak terdapat di wilayah Kabupaten Tabalong, merupakan salah satu unsur budaya tradisional yang pernah dan masih dipertahankan sampai sekarang. Keberadaan Baluntang ini menjelaskan bahwa untuk sementara ini masyarakat masih memperhatikan dan melakukan adat tradisional yang merupakan warisan budaya nenek moyang mereka. Tidak dapat dipungkiri pengaruh pembangunan dan pergeseran kepercayaan masyarakat sedikit banyak turut berpengaruh pada kelestarian warisan budaya tradsional. Dengan pembangunan infrastruktur serta sarana transportasi darat yang cukup pesat di wilayah Kalimantan Selatan, membuat hubungan antardaerah semakin cepat dan terbuka. Keterbukaan isolasi daerah inilah yang membawa berbagai unsur budaya lain masuk dan mempengaruhi sendi-sendi kehidupan masyarakat Tabalong. 
Kebudayaan tradisional masyarakat pun tidak luput dari pengaruh di atas. Memang kebudayaan merupakan sesuatu yang sifatnya dinamis, yang selalu berubah sesuai dengan kondisi lingkungan dan tingkat kebutuhan hidup masyarakatnya. Unsurunsur kebudayaan luar dapat menjadi aktor penting yang merubah wujud kebudayaan lama menjadi kebudayaan baru yang lebih sesuai dan menjamin kesejahteraan masyarakatnya. Dalam konteks perubahan kebudayaan, terdapat pengertian bahwa perubahan yang terjadi pada suatu kebudayaan itu dapat dikategorikan dalam dua kelompok, yaitu morphostatis dan morphogenesis. Morphostatis adalah kondisi dimana perubahan-perubahan yang terjadi tidak membawa perubahan bentuk kebudayaan asli, sehingga sifatnya memperkaya unsure kebudayaan lama. Sedangkan morphogenesis adalah jika perubahanperubahan yang terjadi itu membawa perubahan bentuk atau wujud kebudayaan asli, sehingga terbentuk bentuk kebudayaan baru yang berbeda dengan yang aslinya.

Sehubungan dengan konsep teori perubahan kebudayaan di atas, ada satu permasalahan yang juga sangat terkait dengan perubahan atau pergeseran nilai dan makna yang terjadi pada sebuah Baluntang. Menurut informasi para tetua adat setempat, sejak dahulu masyarakat mengenal Baluntang sebagai tiang kayu pengikat kerbau, yang memiliki nilai sakral dan magis karena juga dianggap sebagai simbol atau lambang si mati serta sebagai tempat memuja dan memohon kemurahan rejeki pada Tuhan Yang Maha Esa. Nilai dan makna Baluntang seperti itu memang sangat dipegang teguh oleh hampir seluruh penduduk, meskipun pada saat ini mereka sudah banyak yang memeluk agama Kristen atau Islam.

Persepsi masyarakat tersebut secara tidak langsung membawa dampak positif bagi kelestarian Baluntang-baluntang yang terdapat di wilayah Kabupaten Tabalong. Meskipun keberadaan Baluntang berada pada tempat-tempat yang terbuka dan tidak pernah diawasi secara langsung, persepsi akan nilai dan makna Baluntang yang tertanam begitu dalam pada diri masyarakat secara umum merupakan pagar abstrak yang dapat melindungi Baluntang dari tindak pencurian atau perusakan lainnya. Hal seperti ini ternyata tidak berlangsung lama, karena sekitar tahun 1976 mulai ramai terjadi tindak pencurian patung Baluntang yang mungkin tidak hanya terjadi di wilayah Kabupaten Tabalong. Akibatnya bisa dilihat bahwa keberadaan Baluntang-baluntang di hampir semua tempat di wilayah Tabalong mulai berkurang karena banyak yang hilang dicuri oleh orang-orang yang tidak bertanggungjawab.

Berdasarkan keterangan di atas, permasalahan perubahan nilai dan makna Baluntang yang terjadi pada masyarakat kemungkinan besar mempunyai pengaruh yang kuat terhadap kelestariannya. Pada saat kerja instansi terkait yang berwenang dalam pemeliharaan dan pelestarian $\mathrm{BCB}$ belum maksimal, serta belum adanya 
koordinasi yang baik antarinstasi pemerintah yang menangani pembangunan bidang budaya, seharusnya masyarakat mempunyai cara tersendiri yang merupakan filter untuk menangani masalah pelestarian sumberdaya budaya mereka. Bagaimana perubahan nilai dan makna sebuah Baluntang dapat mempengaruhi proses pemeliharaan dan kelestarian sumberdaya budaya di wilayah Kabupaten Tabalong, merupakan permasalahan utama yang ingin diketengahkan penulis dalam makalah ini.

\section{Pembahasan}

Dalam kehidupan masyarakat Kabupaten Tabalong, Baluntang mempunyai nilai, arti, dan makna yang spesifik yang sarat akan nuansa religius, karena erat kaitannya dengan pelaksanaan upacara kematian (Mambatur) dan upacara kehidupan (Mambuntang). Dalam upacara Mambatur, keluarga si mati dapat menyelenggarakan upacara penghantaran roh si mati menuju ke tempatnya. Pembuatan Baluntang untuk upacara Mambatur kemudian dapat berkembang sebagai tanda peringatan dan pengagungan roh si mati. Sedangkan upacara Mambuntang, dilakukan sebagai ucapan syukur dan terima kasih masyarakat atas limpahan berkah serta rejeki yang berlimpah ruah, keselamatan, kesehatan atau karena adanya sesuatu janji tertentu. Berdasarkan jenis upacaranya, terdapat perbedaan yang sangat mendasar terhadap arah hadap Baluntang yang didirikan. Bentuk dan posisi patung dalam penggambaran Baluntang pada kedua upacara tersebut tidak ada perbedaan. Hanya arah hadap atau orientasi Baluntang untuk upacara Mambatur dan Mambuntang yang berbeda. Baluntang pada upacara Mambatur mempunyai orientasi arah hadap ke arah barat (matahari terbenam), sedangkan Baluntang pada upacara Mambuntang mempunyai orientasi arah hadap ke timur (matahari terbit).

Orientasi arah hadap Baluntang ini berhubungan dengan kebutuhan dan pengharapan yang diperlukan masyarakat setempat. Untuk menghantarkan roh si mati dalam perjalanan menuju ke surga, Baluntang yang didirikan sengaja diarahkan ke arah barat, yaitu pada arah matahari terbenam. Arah matahari terbenam ini diyakini sebagai arah kembalinya roh manusia. Sedangkan untuk upacara yang berhubungan dengan kegiatan kehidupan, Baluntang diarahkan ke timur ke arah matahari terbit. Arah timur diyakini sebagai awal perjalanan kehidupan manusia sehingga diharapkan akan menemui hal-hal baru yang bermanfaat dan memberikan kesejahteraan baru pada kehidupan yang kemudian.

Perspektif dan pandangan masyarakat Tabalong tentang Baluntang sampai sekitar tahun 1976 masih terjaga dengan baik. Tetapi setelah itu, terjadi perubahan dan pergeseran nilai dan makna Baluntang pada masyarakat. Perubahan dan pergeseran nilai inilah yang kemudian menjadikan Baluntang-baluntang yang terdapat di desa-desa di wilayah Tabalong, mulai terancam kelestariannya. Sedikit 
demi sedikit keberadaan Baluntang-baluntang mulai hilang satu persatu digerogoti oleh pencurian dan perusakan yang dilakukan oleh sekelompok orang yang tidak bertanggungjawab.

Banyak sudah Baluntang rusak dengan cara dipotong atau digergaji patungnya, karena untuk mengambil secara keseluruhan sangatlah sulit, sehingga lebih mudah jika cuma diambil patungnya saja. Beberapa Baluntang yang terdapat di desa-desa di wilayah Tabalong sekarang tinggal berupa tiang-tiang saja, karena patungnya sudah dipotong dan diambil orang. Bahkan ada informasi yang sempat terekam bahwa di daerah Bali, banyak terdapat galeri-galeri budaya yang memperjualbelikan patung-patung tradisional yang unik dari seluruh kawasan di Indonesia, termasuk dari Kalimantan. Bukan tidak mungkin patung-patung Baluntang yang dipotong atau dicuri dari wilayah Tabalong sampai juga di galeri tersebut.

Masalah pemeliharaan dan pelestarian Baluntang-baluntang yang merupakan salah satu unsur budaya tradisional bukan hanya menjadi tugas pemerintah saja. Semua komponen dan anggota masyarakat juga mempunyai tugas yang sama, apalagi bagi kelompok masyarakat yang tinggal di sekitar sumberdaya budaya tersebut. Sebagai pendukung kebudayaan, masyarakat perlu aktif untuk menanggapi perubahanperubahan yang terjadi berhubungan dengan kehidupan mereka. Pergeseran dan perubahan yang terjadi pada beberapa hal memang tidak dapat dihindari, karena pada dasarnya suatu kebudayaan akan selalu berubah sesuai dengan kebutuhan masyarakat dan kondisi lingkungan kehidupan sekitarnya. Nilai-nilai baru yang dianggap dapat memberikan tingkat kesejahteraan yang lebih baik tentunya akan dipilih dan dikembangkan untuk mengganti nilai-nilai lama yang dianggap sudah tidak cocok dengan kebutuhan hidup mereka.

Kebudayaan masyarakat Tabalong juga mengalami hal yang serupa. Dalam perjalanannya, masyarakat Tabalong banyak menemui hal-hal baru yang mau tidak mau harus mereka terima dalam kehidupan mereka. Seperti misalnya, masalah penggabungan kepercayaan lama mereka (kaharingan) dengan agama Hindu. Penggabungan ini adalah tuntutan dari adanya pengakuan pemerintah tentang lima jenis agama yang diakui di negara republik ini. Untuk mendapatkan pengakuan tersebut, mereka harus mau bergabung dengan agama Hindu, yang memang mempunyai kedekatan prinsip dengan konsep kepercayaan tradisional mereka, yaitu Kaharingan.

Penggabungan kepercayaan Kaharingan dengan agama Hindu kemudian membawa perubahan perilaku sebagian besar masyarakat dalam melakukan ritual keagamaan. Jika pada masa sebelum bergabung dengan agama Hindu, masyarakat tidak mengenal cara sembahyang, mereka hanya mengenal upacara-upacara ritual tradisional sebagai media untuk bertemu atau berhubungan dengan Tuhan atau 
Dewa yang mereka sembah. Setelah bergabung, mereka mulai mengenal sembahyang dan waktu-waktu tertentu untuk melakukannya. Meskipun demikian, tampaknya pengaruh agama Hindu tersebut tidak begitu dalam merasuki masyarakat, karena mereka masih tetap menjalankan adat istiadat leluhur yang dirasa lebih cocok untuk kebutuhan mereka. Hal ini dapat terjadi karena dalam kehidupan masyarakat Tabalong, terutama pada kelompok Orang Maanyan atau Orang Lawangan terdapat semacam kewajiban untuk menghormati leluhur mereka. Tatacara penghormatan leluhur mereka itu hanya bisa dilakukan dengan adat istiadat leluhur juga, sehingga mereka masih melakukan beberapa upacara adat terutama yang berhubungan dengan kematian. Upacara kematian ini bagi masyarakat tradisional sangat lah bermakna, karena hanya dengan upacara tersebut mereka dapat menghantarkan roh leluhur mereka menuju ke alamnya sebagai salah satu kewajiban keluarga.

Berdasarkan bentuk dan sistem upacara kematian yang dilakukan, Dyson dan Asharini membedakannya dalam dua kelompok besar, yaitu kelompok pertama adalah kelompok Orang Ngaju-Ot Danum, dan kelompok kedua adalah kelompok Orang Maanyan-Lawangan. Kelompok Orang Ngaju dalam kehidupan mereka lebih menitikberatkan pada pelaksanaan upacara-upacara yang berhubungan dengan kehidupan di akherat (gawi matey). Upacara kematian tersebut dilaksanakan dengan menggunakan bahasa Sangiang, yang merupakan bahasa Ngaju kuna yang sekarang hanya diketahui oleh sebagian kecil di antara mereka, terutama para Balian. Sementara pada kelompok Orang Maanyan-Lawangan lebih menitikberatkan pada upacara-upacara yang berkaitan dengan hajat kehidupan seperti kelahiran, perkawinan, penyembuhan penyakit, tolak bala dan lainnya (gawi belum). Upacara adat tersebut dilakukan dengan menggunakan bahasa Lawangan kuna yang disebut dengan bahasa Pangunraun (Dyson dan Asharini $1980 / 1981 ; 21)$.

Selain penggabungan kepercayaan, tingkat pendidikan masyarakat yang semakin meningkat dan terbukanya komunikasi dan transportasi yang semakin mudah membawa perubahan-perubahan dalam kehidupan masyarakat. Kalau dulu mereka hanya mengenal daerahnya sendiri, sekarang mereka lebih banyak mengenal lingkungan di luar daerahnya. Pengenalan ini kemudian berlanjut pada ketergantungan akan produk atau jasa yang dibutuhkan yang didapatkan dari luar lingkungan asal, sehingga perilaku mereka akhirnya lebih memfokuskan pada kondisi yang terjadi di luar. Perubahan pandangan tersebut tentunya membawa pengaruh juga pada nilai dan makna sumberdaya budaya yang terdapat di sekitar mereka.

Jika selama ini sumberdaya budaya itu dipandang sebagai sesuatu yang sakral dan dihormati serta dijaga keberadaan oleh semua warga masyarakat desa, perlahan tapi pasti mulai ditinggalkan, sehingga banyak yang tidak terpelihara dengan baik. 
Kondisi ini diperparah dengan adanya pengetahuan bahwa sumberdaya budaya yang selama ini hanya mereka lihat dan dipandang tiap hari, ternyata mempunyai nilai ekonomis yang cukup tinggi. Di luar lingkungan mereka ternyata terdapat beberapa kelompok orang yang begitu tertarik untuk dapat memiliki sumberdaya budaya tersebut. Sejumlah uang tertentu yang ditawarkan mungkin bisa mempengaruhi beberapa warga masyarakat untuk melakukan tindakan "rekayasa" agar dapat memiliki sumberdaya budaya yang seharusnya dilindungi.

Bagi sebagian besar masyarakat, Baluntang mungkin sudah tidak mempunyai arti dan makna yang penting lagi dalam kehidupannya. Nilai sakral yang begitu diagungkan pada masa sebelumnya tampaknya mulai luntur. Mereka sudah tidak "takut" lagi terhadap kepercayaan akan adanya roh yang menunggu dan menjaga Baluntang tersebut, sehingga berani mengambil patung tersebut dengan cara memotong atau menggergajinya. Semua itu mereka lakukan dengan imbalan sejumlah uang yang ditawarkan oleh para kolektor benda budaya. Mereka tidak merasakan adanya keterikatan batin lagi dengan budaya dan adat istiadat tradisional, karena mereka telah memeluk agama yang berbeda dengan leluhur mereka. Pertimbangan-pertimbangan tersebut kemungkinan besar mempunyai pengaruh yang besar pada terjadinya perubahan nilai dan makna Baluntang pada masyarakat. Perubahan nilai dan makna ini membuat perilaku masyarakat juga berubah dengan tidak lagi menganggap benda tersebut sebagai barang yang sakral, sehingga kelestariannya tidak diperhatikan lagi oleh masyarakat setempat. Akibatnya mulai tahun 1970-an banyak Baluntang yang ada di wilayah Kabupaten Tabalong mulai hilang dicuri orang yang tidak bertanggungjawab. Bahkan pada satu galeri budaya di Bali (Denpasar) dilaporkan terdapat patung kayu yang mirip dengan penggambaran patung kayu pada Baluntang. Jika hal ini dibiarkan terus bukan tidak mungkin keberadaan Baluntang-baluntang yang masih tersisa sekarang akan mengalami peristiwa yang sama, dirusak dan dicuri patungnya. Akankah kita membiarkan Baluntang-baluntang tersebut hanya menjadi sebatang tonggak kayu tertancap di tanah, tanpa arti dan makna lagi.

Ketika perhatian pemerintah terhadap kelestarian sumberdaya budaya termasuk Baluntang semakin berkurang, seharusnya kita dapat membangkitkan kebanggaan dan rasa memiliki masyarakat terhadap sumberdaya budaya mereka sendiri. Kebanggaan akan kebudayaan dan adat istiadat sendiri mutlak diperlukan dalam rangka membentengi diri dari pengaruh kebudayaan asing yang banyak masuk ke lingkungan kehidupan masyarakat kita dewasa ini. Pengaruh globalisasi dan keterbukaan di segala bidang kehidupan memang membawa dampak yang cukup kuat, sehingga jika tidak waspada kita akan hanyut terbawa arus perubahan yang demikian besar. Masalah pelestarian dan pemeliharaan sumberdaya budaya sebenarnya merupakan tugas kita semua, bukan saja pemerintah dengan aparat yang terkait. Dalam konteks pelestarian inilah peran serta dan partisipasi masyarakat sangatlah penting, terutama yang bertempat tinggal di sekitar 
sumberdaya budaya tersebut. Mereka dapat berfungsi sebagai petugas pertama yang langsung dapat mengawasi dan menjaga kelestarian sumberdaya budaya tersebut.

\section{Kesimpulan}

Seharusnya sebagai salah satu unsur kebudayaan, keberadaan Baluntang sebagai bukti penting tentang pernah berlangsungnya satu upacara ritual tradisional di kalangan masyarakat Tabalong, seharusnya mendapatkan perhatian dan pemeliharaan yang baik. Perhatian itu wajar saja karena keberadaan Baluntang yang pada umumnya terdapat di halaman rumah penduduk, tentunya tidak memerlukan pengawasan dan pemeliharaan yang susah, karena dapat dilakukan sewaktu-waktu oleh keluarga ahli waris atau masyarakat lainnya. Akan tetapi yang terjadi tidaklah demikian, kondisi Baluntang yang terdapat di beberapa desa di wilayah Kabupaten Tabalong ini sangat memprihatinkan. Tampaknya ada perubahan atau pergeseran nilai dan pandangan masyarakat terhadap keberadaan Baluntang-baluntang ini.

Perubahan nilai dan makna Baluntang bisa terjadi karena adanya beberapa faktor penyebab, seperti misalnya adanya penggabungan kepercayaan lama (Kaharingan) dalam agama Hindu. Penggabungan ini membawa dampak terhadap perilaku mereka terhadap adat ritual tradisi lama. Meskipun dalam kenyataannya mereka tetap melaksanakan upacara adat ritual lama, tetapi pelaksanaan upacara tersebut hanyalah rutinitas belaka sebagai perwujudan rasa hormat mereka terhadap leluhur. Dengan kondisi dan latarbelakang demikian tentunya apa yang dilakukan itu akan memberi kesan yang kurang baik, karena di hati mereka ada pertentangan batin yang cukup hebat antara menghormati leluhur dengan mematuhi ajaran agama yang baru. Selain itu, keterbukaan dan hubungan yang lebih baik serta meningkatnya pendidikan masyarakat juga turut berpengaruh pada perubahan nilai dan makna terhadap Baluntang. Sekarang sebagian besar anggota masyarakat tidak lagi memandang Baluntang sebagai sesuatu yang sakral dan diagungkan seperti pada masa lalu. Mereka malah memandang Baluntang sebagai hasil karya seni tradisional yang mempunyai nilai ekonomis yang cukup tinggi yang banyak dicari oleh para kolektor barang-barang antik. Anggapan ini muncul karena tidak adanya lagi keterikatan batin di antara sebagian besar masyarakat terhadap sumberdaya budaya mereka sendiri. Dengan kata lain, perubahan nilai dan makna Baluntang ini ternyata membawa dampak yang kurang menguntungkan bagi pelestarian dan pemeliharaan Baluntang sebagai salah satu sumberdaya budaya warisan leluhur yang seharusnya kita jaga dan lestarikan bersama. 


\section{DAFTAR PUSTAKA}

Dyson, L. dan Asharini, 1980/1981. Tiwah, Upacara Kematian Pada Masyarakat Dayak Ngaju di Kalimantan Tengah. Proyek Media Kebudayaan, Departemen Pendidikan dan Kebudayaan, Jakarta.

Hartatik, 2001. "Survei Konsep dan Bentuk Bangunan Kubur Masyarakat Dayak di Wilayah Kecamatan Tanta, Upau, dan Muara Uya, Kabupaten Tabalong, Kalimantan Selatan". Laporan Penelitian Arkeologi, Balai Arkeologi Banjarmasin, belum terbit.

Pikrinadi, Usah, 1990. "Upacara Mia (Mambatur) Dalam Perspektif Budaya Suku Maanyan, Desa Warukin, Kabupaten Tabalong". Tesis. Fakultas Keguruan dan Ilmu Pendidikan Universitas Lambung Mangkurat, Banjarmasin.

Rampai, Kiwok. D., 1983. "Bangunan Makam Orang Ngaju di Kalimantan Tengah : Suatu Studi Ethnoarkeologi”. Tesis. Yogyakarta: Fakultas Sastra, Universitas Gadjah Mada.

Syariffuddin, R., et.al., 1996. Wujud, Arti dan Fungsi Puncak-puncak Kebudayaan Lama dan Asli Bagi Pendukungnya di Daerah Kalimantan Selatan. C.V. Prisma Muda Banjarmasin.

Syariffuddin, R. dan Maswan Syukrani, 1984. Upacara Marabia. Laporan Hasil Observasi dan Penelitian Bidang Permuseuman Kantor Wilayah Departemen Pendidikan dan Kebudayaan Kalimantan Selatan dan Museum Negeri Lambung Mangkurat.

Sugiyanto, Bambang, 2002. "Arti dan Makna Baluntang pada Masyarakat Tabalong, Kalimantan Selatan". Bulletin Bandarmasih Vol. Museum Negeri Lambung Mangkurat, Banjarbaru.

Sulistyanto, Bambang dan Vida Pervaya Rusianti Kusmartono, 1999/2000. "Penelitian Pemukiman Situs Haringen, Kalimantan Tengah". Laporan Penelitian Arkeologi. Balai Arkeologi Banjarmasin. Belum terbit.

Sulistyanto, Bambang, 2003. Balung Buto: Warisan Budaya Dunia dalam Perspektif Masyarakat Sangiran. Penerbit Kunci Ilmu, Jogjakarta. 